\title{
Home range and multiscale habitat selection of threatened thin-spined porcupine in the Brazilian Atlantic Forest
}

\author{
Gastón Andrés Fernandez Giné, Eduardo Hoffmam de Barros, José Maurício Barbanti Duarte, and \\ DEBORAH FARIA
}

Programa de Pós-graduação em Ecologia e Conservação da Biodiversidade, Departamento de Ciências Biológicas, Universidade Estadual de Santa Cruz,(UESC), Rodovia Ilhéus-Itabuna, Km 16, Ilhéus, Bahia CEP 45650-000, Brazil (GAFG, $E H B, D F)$

Núcleo de Pesquisa e Conservação de Cervídeos (NUPECCE), Departamento de Zootecnia, Faculdade de Ciências Agrárias e Veterinárias (FCAV), Universidade Estadual Paulista Júlio Mesquita Filho (UNESP), Jaboticabal, São Paulo CEP 14884-900, Brazil (JMBD)

* Correspondent: gastongine10@ gmail.com

The threatened and poorly known thin-spined porcupine (Chaetomys subspinosus) is endemic to the highly deforested central portion of the Atlantic Forest of eastern Brazil. In southern Bahia, anecdotal observations suggested that native forest and shade cacao (Theobroma cacao) plantations are important habitats for this species. However, no studies have examined habitat preferences. We estimated the home-range size and determined the factors influencing habitat selection at landscape, home range, and tree scales in the cacao-growing region of southern Bahia. Radiotelemetry data from 21 individuals followed for 3-25 months from April 2005 to November 2013 showed a relatively small home range (0.5-9.5 ha using minimum convex polygon methods), with males showing larger home ranges than females. Habitat selection was congruent across spatial scales, with preference for structurally complex environments at all scales. The tagged porcupines preferred trees that were large, harboring many lianas, and closer to forest limits. Tree selection was specific for each animal activity. On landscape and home-range scales, they preferred secondary forest and avoided structurally simplified, highly disturbed vegetation types such as shade cacao and rubber plantations, early secondary forest, and open areas. All these man-modified habitats were rarely used, if at all, which considerably reduces the suitable habitat within the core distribution area and profoundly impacts conservation.

O ouriço-preto Chaetomys subspinosus é uma espécie endêmica e pouco conhecida da porção central da Mata Atlântica, leste do Brasil, hoje altamente desmatada. No sul da Bahia, observações anedóticas sugerem que florestas nativas e plantações sombreadas de cacau (Theobroma cacao) são importantes habitats para esta espécie. Não existe estudo, entretanto, sobre as preferências de habitat desta espécie. Nós estimamos o tamanho da área de vida e determinamos os fatores que influenciam a seleção de habitat pelo ouriço-preto em nível de paisagem, área de vida e árvore na região cacaueira do sul da Bahia. Nós analisamos dados obtidos por radiotelemetria de 21 indivíduos seguidos durante três a 25 meses de Abril 2005 a Novembro 2013. Os animais apresentaram relativamente pequena área de vida ( 0,5 a 9,5 ha, usando o método mínimo polígono convexo) com machos apresentando maior tamanho de área de vida do que fêmea. A seleção do habitat foi congruente através das escalas espaciais, com preferência para ambientes estruturalmente complexos em todas as escalas. Em nível de árvore, os ouriços marcados preferiram grandes árvores, árvores com muitas lianas e árvores mais próximas aos limites do fragmento florestal. A seleção de árvores foi específica para cada atividade animal e nós oferecemos detalhes. Para ambas as escalas, paisagem e área de vida, eles preferiram florestas secundárias avançadas, enquanto evitaram ou não preferiram tipos de vegetação simplificados e altamente alterados tais como plantações sombreados de cacau e seringas, florestas secundárias iniciais e áreas abertas. Estes habitats modificados pelo homem foram usados raramente ou não usados, o que reduz consideravelmente a quantidade estimada de habitat adequado disponível para a espécie dentro da área nuclear de sua distribuição, com um profundo impacto para sua conservação.

Key words: arboreal folivore, Chaetomys subspinosus, porcupine, shade cacao plantation, spatial ecology

(C) 2015 American Society of Mammalogists, www.mammalogy.org 
Home range and habitat selection are ecological processes that are largely explained by species requirements and their abilities to explore and choose available resources. These processes ultimately affect individual fitness, population distribution, and niche evolution (Holt and Barfield 2008; Spencer 2012). Required habitat features and factors influencing choices vary for different spatial scales (Morin et al. 2005). Johnson (1980) identified 4 orders of spatial scale habitat component selection: geographic range, individual home-range establishment in a landscape, the habitats used by an individual within its home range, and the individual resources selected within each habitat. Although the selection of a resource on one spatial scale can be influenced by processes on other scales, the criteria, magnitude, and direction of selection are not necessarily congruent across scales. For instance, food abundance may explain the selection of patches in a habitat, but food-rich habitats may not be preferred among those in the home range or at broader scales. Such incongruence can occur when the habitats do not satisfy other important survival needs (Morin et al. 2005).

Therefore, understanding space use and habitat selection patterns in a multiscale approach is essential for the conservation of threatened populations (Boyd et al. 2008). Such knowledge has practical implications for management, particularly for identifying key habitats and needed resources or providing information on capacity to explore and adapt to modified habitats (Boyd et al. 2008; Holt and Barfield 2008). Nevertheless, limited information is available, particularly for secretive species in tropical forests.

One such species is the thin-spined porcupine (Chaetomys subspinosus), the only New World porcupine (Rodentia: Erethizontidae) considered threatened by the International Union for Conservation of Nature (IUCN 2014). It is a monotypic species (Vilela et al. 2009; Voss et al. 2013), weighing $1.5-2.0 \mathrm{~kg}$ with nocturnal and arboreal habits (Chiarello et al. 1997; Giné et al. 2012; Oliveira et al. 2012). The species is probably the most folivorous among the erethizontids studied to date (Giné et al. 2010; de Souto Lima et al. 2010). It is currently threatened mainly because populations are restricted to forest remnants along the central portion of the Atlantic Forest of eastern Brazil (Oliver and Santos 1991), 83\% of which has been destroyed by lumbering and agricultural clearing (Ribeiro et al. 2009).

Earlier studies on space and habitat use by the thin-spined porcupine focused on home-range size, daily displacement, and use of resources such as substrates, diurnal shelters, latrines, and foods (Chiarello et al. 1997; de Souto Lima et al. 2010; Giné et al. 2010; Zortéa and de Brito 2010; Giné et al. 2012; Oliveira et al. 2012). So far, no published studies have evaluated habitat selection, and most provide only general habitat descriptions. Restinga forest (Brazilian sandbank forest), seasonal forest (semideciduous forest), and evergreen rainforest (ombrophilous forest) from early to advanced successional stage are native vegetation where this species exists (Moojen 1952; Oliver and Santos 1991; Faria et al. 2011).

Within its geographic distribution, the thin-spined porcupine is mainly associated with extensive forest-covered areas in southern Bahia (Oliver and Santos 1991), suggesting that the region harbors the largest contiguous population. However, a significant portion of the forest cover comprises shade cacao (Theobroma cacao) plantations, mostly under traditional management locally known as cabruca (May and Rocha 1996). In these traditional shade cacao plantations (SCPs), cacao shrubs have completely replaced native understory with only a few native tree species left for shade. Although SCPs are highly disturbed and managed forested habitats, they maintain a simpler but still stratified forest structure, a key feature explaining why these habitats are occupied by many species of the regional biota (Faria et al. 2007; Pardini et al. 2009; Cassano et al. 2014a, 2014b), including some arboreal species such as primates (Raboy and Dietz 2004; Oliveira et al. 2011b) and sloths (Cassano et al. 2011).

SCPs have been considered as habitats for thin-spined porcupines (Moojen 1952; Nowak and Paradiso 1983), although one study based on local knowledge suggested that they serve only as temporary refuges (Oliver and Santos 1991). Given the wide area covered by SCPs, it is important for conservation purposes to establish whether they are suitable habitats for this species. Therefore, we investigated habitat selection and space use patterns in this region as part of research to support decisions by the National Action Plan for the conservation of this species (Faria et al. 2011).

Our objectives were 1) to estimate the home-range size in the region; 2) to analyze habitat selection and its congruence in 3 hierarchical spatial scales including landscape, home range, and tree levels; and 3) to evaluate the influence of structural forest characteristics on animal decisions. We expected that specific vegetation features such as those related to canopy connectivity and key resource concentration would be important factors driving habitat selection on different scales, and that structurally simplified habitats such as SCPs would be avoided.

\section{Material ANd Methods}

Study area.-We conducted this research in the cacao growing region of southern Bahia state, including the municipalities of Uruçuca, Ilhéus, and Una $\left(38^{\circ} 90^{\prime}-39^{\circ} 32^{\prime} \mathrm{W}\right.$ and $14^{\circ} 29^{\prime}-15^{\circ} 23^{\prime} \mathrm{S}$ ), eastern Brazil (Fig. 1). The local annual average temperature is $24-25^{\circ} \mathrm{C}$, and the annual rainfall averages $2,000 \mathrm{~mm} /$ year with no typical dry season (Mori et al. 1983). The bulk of the remaining forest is located along the poor sandy coastal soils. These evergreen forests are classified as tropical lowland rainforest (Oliveira-Filho and Fontes 2000) characterized by tall canopy (20-30 m) with abundant epiphytes, ferns, bromeliads, and lianas (Thomas et al. 1998). In contrast, the cacao production is spatially concentrated further west with extensive SCPs dominating landscapes along a north-south belt of productive soils mostly $15-20 \mathrm{~km}$ from the coast (May and Rocha 1996).

In order to access habitat selection in landscapes with contrasting representation of SCPs and native forests, we monitored individuals in cacao farms, as well as individuals in some of the largest protected areas along the coast (Fig. 1), 


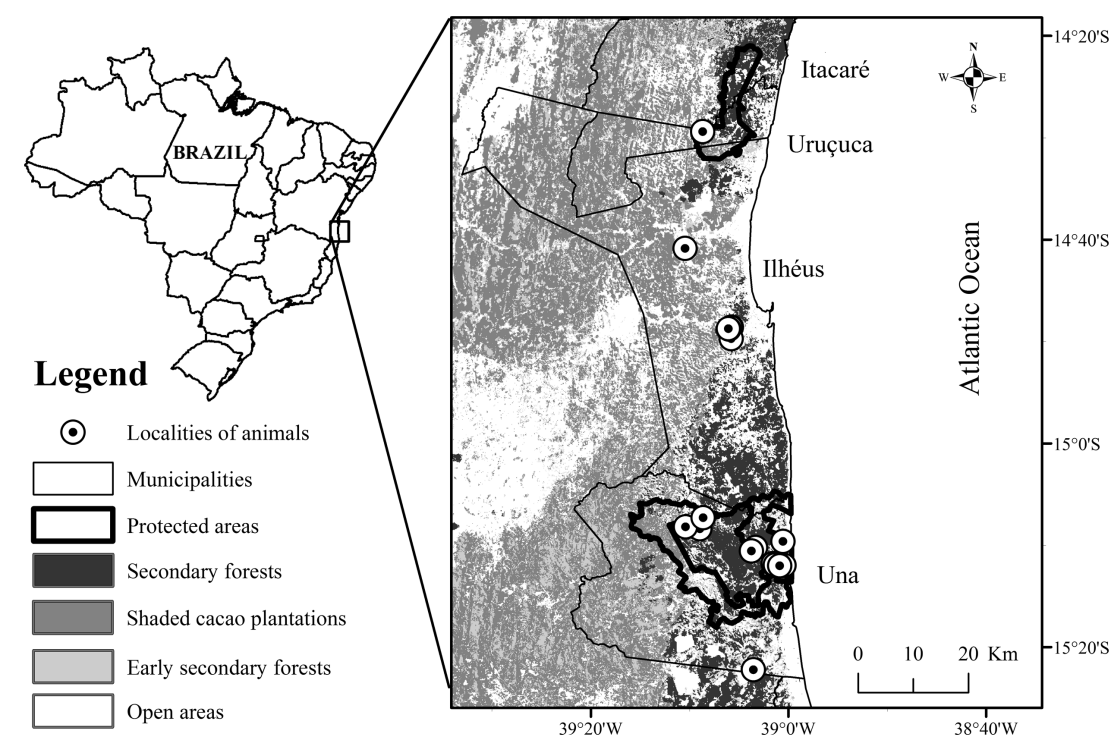

Fig. 1.-Location of the study area and distribution of the thin-spined porcupines tracked in the cocoa-producing region of southern Bahia, Brazil. Circles represent the center of each individual's home range. Protected areas (bold black lines) are Serra do Conduru State Park (north portion of map), the Una Biological Reserve (south portion of map), and the Una Wildlife Refuge (around of the Una Biological Reserve).

such as Serra do Conduru State Park (PESC), Una Biological Reserve (REBio-Una), and Una Wildlife Refuge (REVISUna). Native forest remnants used by animals varied from 1 to 18 ha in cocoa farms and from 22 to 12,150 ha in protected areas.

Capture and radiotracking.-We manually captured 21 thin-spined porcupines (5 males and 16 females; Table 1) from trees, fitted them with 40-g radiocollars (Model LB81/MS6A; $3.9 \times 2.0 \times 1.9 \mathrm{~cm}$; Telonics Inc., Mesa, Arizona), and released them on the same day in the same tree where they were captured. Of these, 16 were adults $(>1.5 \mathrm{~kg}), 4$ subadults $(1-1.5 \mathrm{~kg})$, and 1 infant $(<1 \mathrm{~kg})$ based on body weight and coincident with the juvenile aspect of the pelage and hand palm. Details of the capture, handling, and tagging were described by Giné et al. (2010) and followed the recommendations of the American Society of Mammalogists (Sikes et al. 2011). We located tagged porcupines using a VHF telemetry system (Telonics Inc.; receiver Model TR-4 and antenna Model RA-23K) and marked the tree used by each animal 1-2 times per week for 3-25 months from April 2005 to November 2013 (Table 1). We sampled similarly during both nocturnal and diurnal periods to avoid temporal bias (Kernohan et al. 2001). This resulted in 16-95 locations per individual with at least $24 \mathrm{~h}$ between successive records, totaling 935 locations.

In addition, 4 adult thin-spined porcupines (F2, F3, F4, and M1) inhabiting forest remnants of cocoa farms were followed during 34-42 nocturnal periods of $6 \mathrm{~h}(1800-0000 \mathrm{~h}$ or 0000 $0600 \mathrm{~h}$ ), totaling 146 half-night periods $(944 \mathrm{~h})$ from March 2005 to September 2006. Using an instantaneous scan-sampling method (Altmann 1974), we recorded animal activity (resting, feeding, traveling, defecating, and other activities) every $10 \mathrm{~min}$ and marked the trees that they used. During diurnal sampling periods, we also marked trees used for diurnal rest. We calculated the frequency of visits for each tree, with a visit starting when an animal entered a tree to perform an activity and finishing when it left. Later, we mapped all the trees used during both samplings (24-h interval and 10-min interval) and obtained their geographical positions. Details of the mapping and behavior record were described by Giné et al. (2012). We removed all radiocollars after the sampling period and observed no injuries.

Habitat measure.-We mapped the limits of every vegetation types within and around of the each individual's home range. Vegetation types were delineated on 1:5,000-scale aerial photographs taken in 2001 and 2002, and walking in the field with a GPS (GPSMAP 60CSX; Garmin International, Inc., Olathe, Kansas) for more precise mapping and ground control. Vegetation types were assigned according to structural characteristics as secondary forest (forest in advanced or medium phase of regeneration, average canopy height $>5 \mathrm{~m}$, and average diameter at breast height $[\mathrm{DBH}]>8 \mathrm{~cm}$ ), early secondary forest (forest in initial succession phase of regeneration, average canopy height $<5 \mathrm{~m}$, and average DBH $<8 \mathrm{~cm}$ ), SCP (cacao plantation shade by native trees), rubber plantation (rubber trees planted between native trees), and open area (pasture or conventional nonforested plantations).

We estimated the area occupied by each vegetation type in each individual home range and surrounding landscape (a circular area of 600-m radius [area $113 \mathrm{ha}$ ] around the center of each porcupine's home range). We assumed this would allow us to detect the potential importance of habitat mosaics in the selection process at the landscape level, since the reported maximum daily travel distance is $540 \mathrm{~m}$ (Giné et al. 2012), and radiuses of 500-1,000 $\mathrm{m}$ generally showed no marked changes in the proportions of habitats.

For all trees used by tagged porcupines, we measured DBH, number of lianas (NL), and proximity to forest limit (PFL), i.e., where forest borders other vegetation types. We also sampled the trees available in the home range (MCP100\%) by measuring DBH and NL of all adult trees (with $\mathrm{DBH} \geq 10 \mathrm{~cm}$ ) within 10 randomly sampled plots $(10 \times 10 \mathrm{~m})$ for each individual. We 
Table 1.-Sex, monitoring period, total number of locations, and home-range size of the all thin-spined porcupines radiotracked in Atlantic Forest of southern part of Bahia, Brazil.

\begin{tabular}{lccccr}
\hline Individual $^{\text {a }}$ & Radiotracking & \multirow{2}{*}{$\begin{array}{c}\text { Number of } \\
\text { period }\end{array}$} & locations & \multicolumn{3}{c}{ Home-range size (ha) } \\
\cline { 5 - 6 } & & & MCP100\% & MCP95\% & FK95\% \\
\hline F1 $^{\text {c }}$ & Jan. 05-June 05 & 20 & 1.95 & 1.39 & 3.67 \\
F2 & Mar. 05-Mar. 06 & 45 & 1.50 & 1.07 & 1.25 \\
F3 & June 05-July 06 & 50 & 0.48 & 0.36 & 0.34 \\
F4 & Oct. 05-Sep. 06 & 45 & 1.30 & 1.06 & 1.47 \\
F5 & Sep. 10-Jan. 11 & 16 & 0.80 & 0.79 & 1.69 \\
F6 & May 11-Dec. 11 & 41 & 4.45 & 4.07 & 6.17 \\
F7 & May 11-Jan. 12 & 37 & 1.64 & 1.47 & 2.04 \\
F8 & June 11-Feb. 12 & 50 & 4.60 & 3.45 & 6.06 \\
F9 & Oct. 11-Oct. 13 & 95 & 1.34 & 1.13 & 1.16 \\
F10 & Nov. 11-Mar. 13 & 66 & 1.24 & 0.77 & 0.80 \\
F11 & Jan. 12-May 13 & 74 & 1.84 & 0.96 & 1.55 \\
F12 & Sep. 12-Mar. 13 & 32 & 1.86 & 1.50 & 2.31 \\
F13 & Apr. 13-Nov. 13 & 45 & 2.68 & 2.23 & 3.07 \\
F14 & Apr. 13-Oct. 13 & 43 & 1.41 & 1.16 & 0.44 \\
F15 & May 13-Nov. 13 & 39 & 1.94 & 0.62 & 0.99 \\
F16 & Aug. 13-Nov. 13 & 23 & 2.14 & 1.55 & 3.61 \\
M1 & Aug. 05-Sep. 06 & 49 & 9.46 & 8.63 & 14.07 \\
M2 & Sep. 10-Mar 11 & 48 & 0.81 & 0.76 & 0.69 \\
M3 & Dec. 11-Feb. 12 & 20 & 3.04 & 2.33 & 6.11 \\
M4 & Jan. 13-Aug. 13 & 26 & 9.04 & 8.69 & 17.69 \\
M5 & Jan. 13-Nov. 13 & 71 & 4.72 & 3.37 & 3.80 \\
\hline
\end{tabular}

${ }^{a}$ Identification and sex of radiotagged animals $(\mathrm{F}=$ female, $\mathrm{M}=$ male). ${ }^{\mathrm{b}}$ Home range estimated by minimum convex polygon method using 100 and 95\% of locations (MCP100\% and MCP95\%, respectively) and fixed kernel methods using $95 \%$ of utilization distribution (FK95\%).

c Subadult.

${ }^{\mathrm{d}}$ Infant.

randomized 60 points in each home range in forest remnants and measured the PFLs.

Home-range analysis.-Using the data set of 24-h minimum interval locations, we estimated home-range size using the minimum convex polygon method (MCP100\% and MCP95\%Mohr 1947) and 95\% fixed kernel methods (FK95\%-Worton 1989), choosing the smoothing parameter $h$ by least squares cross validation $\left(h_{\mathrm{lsc}}\right)$. We built an area-observation curve for each individual (Odum and Kuenzler 1955) using bootstrap procedure (100 replicates per run) in order to check the effect of the number of sampled locations on home-range estimations (MCP100\%). We processed home-range estimations and areaobservation curves using Animal Movements Extension version 2.04 (Hooge and Eichenlaub 1997) in ArcView GIS version 3.2 software (Environmental Systems Research Institute, Inc. 1999). Then, we performed $t$-tests to evaluate differences in home-range size of adult males and females. Normal distributions were obtained from logarithmic transformations of values.

Multiscale habitat selection analysis.-We assessed habitat selection with the software package Resource Selection for Windows version 1.0 (Leban 1999) using the individual as a sampling unit. We applied the chi-square goodness-of-fit test and Bonferroni confidence intervals a posteriori (Neu et al. 1974) and contrasted habitat use versus habitat availability to detect habitat selection. When the use of a habitat category did not differ significantly from the amount expected, considering its availability, the habitat was considered as not being selected (a random use). Otherwise, the habitat was considered to be preferred (more frequently used than expected) or avoided (less frequently used that expected-Byers et al. 1984). We included only adult and subadult individuals with more than 30 locations in these analyses $(n=15)$.

We evaluated habitat selection through 3 hierarchical spatial scales according to the 4 scales proposed by Johnson (1980). At the landscape scale (2nd order of selection), we compared the proportion of area occupied by each vegetation type within the individual home range (MCP100\%) with the availability (expected value) of these habitats within the landscape (600-m-radius buffer). At the home-range scale (3rd order), we compared the proportion of 24-h-interval locations in each vegetation type for each porcupine to the relative availability of these habitat types within its MCP100\% home range. At the tree scale (4th order), we compared the proportion of trees used included in attribute categories to the relative availability to individuals in the home range (MCP100\%).

Behavioral use of trees.-Generalized linear mixed models (GLMMs) with Poisson distribution and log link functions were performed on data sets obtained in scan sampling of the 146 half-night periods. This was done to examine the influence of tree attributes (DBH, NL, and PFL) on the total frequency of visits, as well as on the frequency of each of the 4 main activities: diurnal resting, feeding, traveling, and waste deposition. Each animal was fitted as a random effect in all GLMM. To facilitate the interpretation of the effect of PFL, the PFL values were multiplied by -1 . Spearman correlations were performed before GLMM analyses between all tree attribute pairs. Since low correlations $(r<0.2)$ were observed, all attributes were considered in the models.

Models were run using the "glmer" function from the "lme4" package in R software (R Development Core Team 2013). We used the "dredge" function from the "MuMIn" package in the $\mathrm{R}$ environment to test models defined by all possible variable combinations and the null models. We ranked the candidate models based on Akaike's Information Criterion corrected for small sample size (AICc). Models were considered equally plausible to explain the observed pattern when AICc differences $\left(\Delta_{i}\right)$ were lower than 2 (Burnham and Anderson 2002). Then, we determined the best model choosing the most parsimonious model among those with lower AICc and corresponding higher Akaike weights ( $\omega_{i}$-Burnham and Anderson 2002).

Structural differences between vegetation types.-Due to logistic limitations, we managed to assess a series of vegetation features and resource availability for only 2 vegetation types: secondary forests and SCP. We established 10 plots $(10 \times 10 \mathrm{~m})$ $20 \mathrm{~m}$ apart along a 300-m transect of both vegetation types in 4 cocoa farms used by the animals. We identified all trees with $\mathrm{DBH} \geq 10 \mathrm{~cm}$ and recorded DBH, NL, and the presence of lianas, bromeliads, and hollows with diameter $>10 \mathrm{~cm}$, which are potential latrines and shelters for this species (Oliver and Santos 1991; Giné et al. 2012; Oliveira et al. 2012). We also counted the number of potential feeding sources in each plot based on the 4 tree species most consumed: Albizia pedicellaris, Inga 
thibaudiana, Pera glabrata, and Tapirira guianensis (Giné et al. 2010). Finally, we evaluated the vertical foliage profile at 60 random points in both habitat types using a modification of Hubbell and Foster's method (1986). This method involves using a 5-m pole at each point for vertical sighting and estimating the foliage density percentage at each stratum $(0-2,2-5$, $5-10,10-15,15-20$, and $>20 \mathrm{~m})$. Differences between the SCP and secondary forests regarding resource availability and structural features were checked separately for each habitat variable by nonparametric Mann-Whitney test (Siegel 1956).

\section{RESUlTS}

Home range.-The area-observation curves indicated that the home-range size (MCP100\%) stabilized for most porcupines, except for the males M1, M5, and the least sampled (< 30 locations) individuals (F1, F5, F16, M3, M4), indicating that their home ranges could increase (Supporting Information S1). The estimated mean home ranges of the 21 thin-spined porcupines were as follows: $2.77 \mathrm{ha} \pm 2.47 \mathrm{SD}$ (MCP100\%; range: $0.48-9.46 \mathrm{ha}$ ), $2.25 \pm 2.35$ ha (MCP95\%; range: $0.36-8.69 \mathrm{ha}$ ), and 3.76 \pm 4.46 ha (FK95\%; range: 0.34-17.69 ha; Table 1; Supporting Information S2). Even underestimated, the mean home range of adult males was at least 3 times larger than those of females with all methods: MCP100\% (males: $6.56 \pm 3.18$ ha, females: $2.03 \pm 1.31$ ha; $t=-3.468, d . f .=14, P=0.004$ ), MCP95\% (males: $5.75 \pm 3.38$ ha, females: $1.55 \pm 1.15$ ha; $t=-3.456, d . f .=14, P=0.004$ ), and FK95\% (males: $10.42 \pm 6.54$ ha, females: $2.41 \pm 1.97$ ha; $t=-3.351, d . f .=14, P=0.005$ ). The MCP100\% home range of adult males overlapped $94.2 \%$

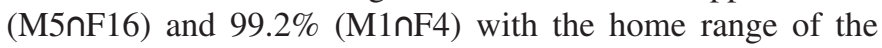
adult females. In contrast, female's home range (MCP100\%) overlapped $13 \%$ (F16nM5) and $45.00 \%$ (F4nM1) with the adult male home range, while it overlapped up to $0.20 \%$ with neighboring adult females $(\mathrm{F} 9 \mathrm{nF} 12=0.20 \%)$. Because we did not monitor males in the same forest remnant, no information about the overlap of male home range was obtained.

Multiscale habitat selection.-At landscape and home-range scales (2nd and 3rd Johnson order), the use of vegetation types was not random (2nd order: $\chi^{2}=776.986$, d.f. $=4, P<0.0001$; 3rd order: $\chi^{2}=100.861$, d.f. $\left.=4, P<0.0001\right)$. At both scales, secondary forest was the single vegetation type preferred, while the remaining types were avoided or not selected (Fig. 2). In particular, tagged porcupines were located predominantly in secondary forests (88.9\%; Supporting Information S2) and rarely in highly modified vegetation types such as early secondary forest $(10.7 \%)$ and SCP $(0.4 \%)$. They were not located in rubber plantations or open areas. All trees used in SCPs were located within a short distance $(<20 \mathrm{~m})$ from forest remnants, which were mainly used for waste deposition (16 times), and on a single occasion, as a diurnal resting site.

At finer scale (4th Johnson order), tagged porcupines clearly selected trees with particular structural features, preferring trees that were large $\left(\mathrm{DBH}>30 \mathrm{~cm}, \chi^{2}=270.29\right.$, d.f. $=4$, $P<0.0001$ ) with moderate to high amounts of lianas (NL $>$ 6 lianas, $\chi^{2}=3316.91$, d.f. $=4, P<0.0001$ ) and close to the
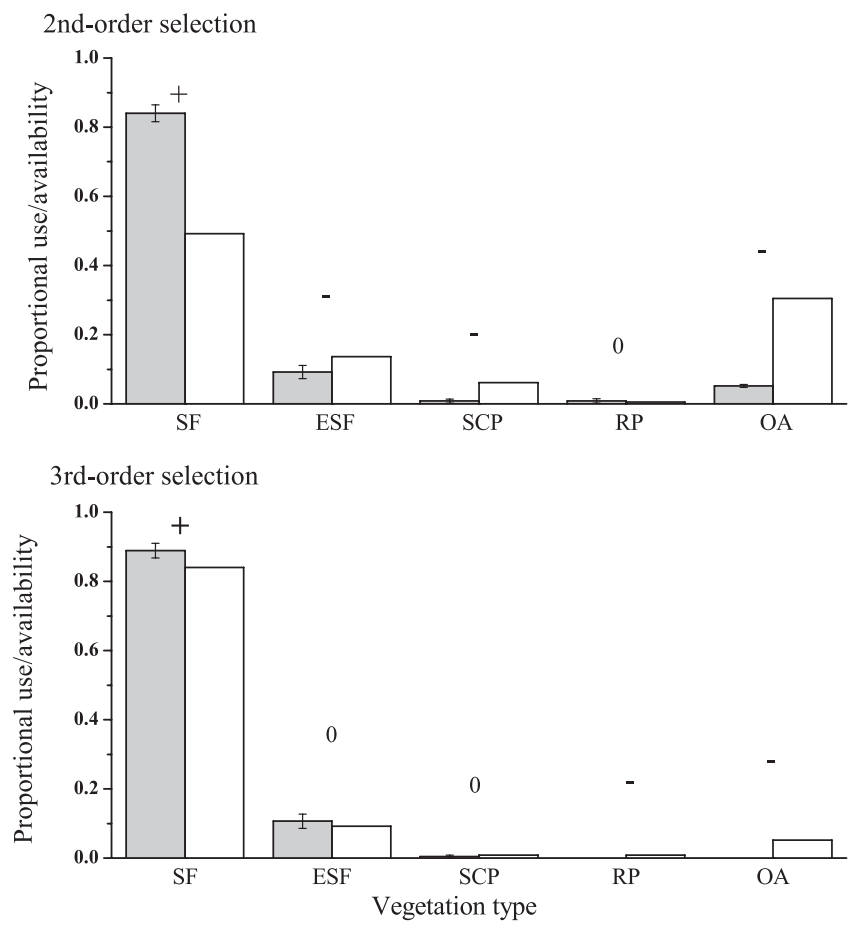

Fig. 2.-Second- and 3rd-order habitat selection (i.e., landscape and home-range scales) by thin-spined porcupines along 5 vegetation types in the Atlantic Forest, Brazil, namely secondary forests (SF), early secondary forests (ESF), shade cacao plantations (SCP), rubber plantations (RP), and open areas (OA). Gray bars indicate mean proportional habitat utilization with Bonferroni confidence intervals (Neu et al. 1974), and white bars indicate mean proportional availability. Positive (+), negative (-), and neutral (0) symbols indicate that the proportional utilization was significantly higher, lower, or equal to availability, respectively $(P<0.05)$.

forest edges (PFL $<10 \mathrm{~m}, \chi^{2}=270.17$, d.f. $=4, P<0.0001$ ). Other trees were avoided or not selected (Fig. 3). The individuals were also seen only in trees, never on the ground.

Behavioral use of trees.-In the 146 half-nights, the 4 radiotagged animals used a total of 490 trees during 1,232 visits $(2.51$ visits/tree). The results indicate that porcupines frequently reused trees for most activities. Seventy-five trees were used during 298 visits for diurnal resting (3.97 visits/tree), 111 trees during 341 feeding visits (3.07 visits/tree), 297 trees exclusively for travelling during 526 visits (1.77 visits/tree), and 15 trees exclusively for waste deposition during 67 visits (4.47 visits/tree). Seven trees were used both to feed and for diurnal rest.

GLMM analyses showed that all attributes evaluated (DBH, NL, and PFL) were important to predict the frequency of general visits to trees given that the best model included all these attributes (Table 2, (a)). Trees with larger diameter (DBH) and $\mathrm{NL}$, as well as closer to forest limits (PFL), were most frequently visited. In addition, although other less parsimonious models were equally plausible, the best model indicated that variables NL and PFL explained the frequency of visits for diurnal resting and travelling (Table 2, (b and c)), while DBH and PFL explained the frequency of visits for feeding (Table 2, (d)). Considering the frequency of visits for waste deposition, 

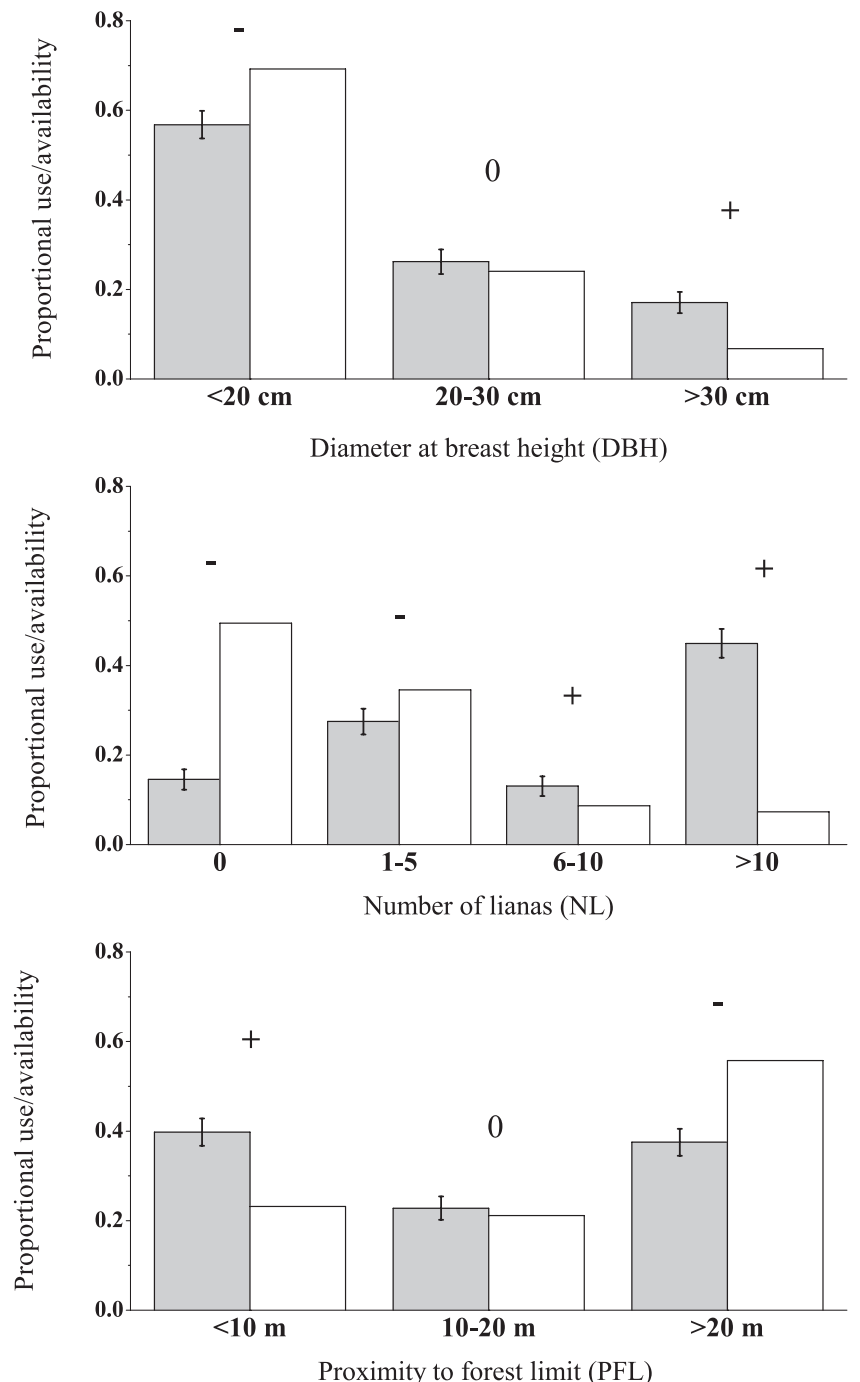

Fig. 3.-Fourth-order selection (tree selection) by thin-spined porcupines in Atlantic Forest, Brazil. Gray bars indicate mean proportional utilization with Bonferroni confidence intervals (Neu et al. 1974), and white bars indicate mean proportional availability. Positive (+), negative (-), and neutral (0) symbols indicate that the proportional utilization was significantly higher, lower, or equal to availability, respectively $(P<0.05)$.

the model including NL and DBH was the best supported (Table 2, (e)). In general, the attributes positively influenced the frequency of visits for all activities, except PFL and NL, which negatively affected the frequency of visits for diurnal resting and waste deposition, respectively. Null models appeared with high $\Delta_{i}(\geq 13.7)$ and low $\omega_{i}(\leq 0.001)$ for all activities.

Structural differences between vegetation types.-The secondary forests (preferred habitat) and SCPs (nonpreferred habitat) did not differ significantly in tree densities and diametric frequency of the trees, and they also presented similar densities of feeding trees (Table 3). Potential structures that could provide shelter and latrine (tangle of lianas, palm trees, hollows, and bromeliads) were also observed in both habitats. On the other hand, the NL in trees, density of canopy trees, and foliage
Table 2.-AICc-based model selection for the frequency of visits of radiotagged thin-spined porcupines (Chaetomys subspinosus) to tree for performed its general activities and 4 main activities: diurnal rest, feed, travel, and defecate. Generalized linear mixed models used the attributes of tree: number of lianas (NL), diameter at breast height (DBH), and proximity to forest limit (PFL) as fixed factors and individual as random factor. We also show the number of degrees of freedom $(K)$, AICc differences $\left(\Delta_{i}\right)$, and Akaike weights $\left(\omega_{i}\right)$.

\begin{tabular}{|c|c|c|c|c|c|c|}
\hline Model rank & Candidate models ${ }^{\mathrm{a}}$ & $K$ & $\mathrm{AICc}$ & $\Delta_{i}$ & $\omega_{i}$ & $\sum \omega_{i}$ \\
\hline \multicolumn{7}{|c|}{ (a) Frequency of general visits (dependent variable) } \\
\hline 1 & $\mathrm{NL}^{+}+\mathrm{DBH}^{+}+\mathrm{PFL}^{+}$ & 5 & 1083.0 & 0.00 & 0.909 & 0.909 \\
\hline \multicolumn{7}{|c|}{ (b) Frequency of visits to diurnal rest } \\
\hline 1 & $\mathrm{NL}^{+}+\mathrm{PFL}^{-}$ & 4 & 345.6 & 0.00 & 0.557 & 0.557 \\
\hline 2 & $\mathrm{NL}^{+}+\mathrm{DBH}^{+}+\mathrm{PFL}^{-}$ & 5 & 347.7 & 2.09 & 0.195 & 0.743 \\
\hline 3 & $\mathrm{NL}^{+}$ & 4 & 347.8 & 2.20 & 0.185 & 0.879 \\
\hline \multicolumn{7}{|c|}{ (c) Frequency of visits to travel } \\
\hline 1 & $\mathrm{NL}^{+}+\mathrm{DBH}^{+}+\mathrm{PFL}^{+}$ & 5 & 223.9 & 0.00 & 0.382 & 0.382 \\
\hline 2 & $\mathrm{NL}^{+}+\mathrm{PFL}^{+}$ & 4 & 224.0 & 0.11 & 0.361 & 0.743 \\
\hline 3 & $\mathrm{NL}^{+}+\mathrm{DBH}^{+}$ & 4 & 226.0 & 2.05 & 0.136 & 0.879 \\
\hline 4 & $\mathrm{NL}^{+}$ & 3 & 226.0 & 2.31 & 0.120 & 0.999 \\
\hline \multicolumn{7}{|c|}{ (d) Frequency of visits to feed } \\
\hline 1 & $\mathrm{NL}^{+}+\mathrm{DBH}^{+}+\mathrm{PFL}^{+}$ & 5 & 333.0 & 0.00 & 0.429 & 0.429 \\
\hline 2 & $\mathrm{DBH}^{+}+\mathrm{PFL}^{+}$ & 4 & 333.1 & 0.07 & 0.413 & 0.842 \\
\hline \multicolumn{7}{|c|}{ (e) Frequency of visits to defecate } \\
\hline 1 & $\mathrm{NL}^{-}+\mathrm{DBH}^{+}$ & 4 & 42.0 & 0.00 & 0.550 & 0.550 \\
\hline 2 & $\mathrm{NL}^{-}+\mathrm{DBH}^{+}+\mathrm{PFL}^{+}$ & 5 & 43.2 & 1.19 & 0.304 & 0.854 \\
\hline 3 & $\mathrm{DBH}^{+}+\mathrm{PFL}^{+}$ & 4 & 44.7 & 2.72 & 0.141 & 0.995 \\
\hline
\end{tabular}

a Only models with Akaike weights $\left(\omega_{i}\right)$ greater than 0.1 are shown. Models with $\Delta_{i}<2$ are considered equally plausible to explain the response variables. Superscripts indicate positive or negative relationships of each variable.

density in the middle stratum $(5-10 \mathrm{~m})$ were significantly lower in the SCPs than in secondary forests. Specifically, SCPs contained no lianas in the trees sampled.

\section{Discussion}

We have provided the most extensive, spatially explicit picture of individual space requirements and habitat use patterns in hierarchical spatial scales for a Southern American porcupine species. Our results indicated that the thin-spined porcupine has relatively small home ranges with adult males using areas at least 3 times larger than females. Habitat selection was congruent across spatial scales, with preference for structurally complex environments on all scales. At landscape and homerange scales, the species preferred secondary forests to more disturbed habitats.

Home range.-Experts have suggested that the minimum number of animal locations is between 30 and 50 for accurately estimating home range using kernel estimators, with more locations required using the MPC method (for a review, see Kernohan et al. 2001). However, the amount of locations required is variable and can be evaluated using the area-observation curve (Odum and Kuenzler 1955). In theory, home-range size estimates reach an asymptote when an adequate sample size is reached (Laundré and Keller 1984). Although the number of locations collected to estimate home ranges was limited in our study, the 
Table 3.- Structural characteristics of 2 vegetation types used by radiotagged thin-spined porcupines (Chaetomys subspinosus) in southern Bahia, Brazil.

\begin{tabular}{|c|c|c|}
\hline \multirow[t]{2}{*}{ Habitat variable ${ }^{\mathrm{a}}$} & \multicolumn{2}{|c|}{ Vegetation types $^{\mathrm{b}}$} \\
\hline & Secondary forest & Shade cacao plantation \\
\hline \multicolumn{3}{|l|}{ Availability of trees } \\
\hline Density of trees & $590.0 \pm 81.9$ & $536.7 \pm 92.9$ \\
\hline Density of canopy trees & $579.0 \pm 80.8 *$ & $146.7 \pm 105.0^{* *}$ \\
\hline Trees with $10-20 \mathrm{~cm}$ of DBH (\%) & $79.0 \pm 07.6$ & $81.4 \pm 09.8$ \\
\hline Trees with $20-30 \mathrm{~cm}$ of DBH (\%) & $13.3 \pm 07.1$ & $10.0 \pm 05.4$ \\
\hline Trees with $>30 \mathrm{~cm}$ of DBH $(\%)$ & $7.8 \pm 04.3$ & $8.6 \pm 04.4$ \\
\hline \multicolumn{3}{|l|}{ Availability of lianas } \\
\hline Trees with 0 lianas $(\%)$ & $33.3 \pm 10.2 *$ & $100.0 \pm 00.0^{* *}$ \\
\hline Trees with 1-5 lianas (\%) & $39.7 \pm 09.6^{*}$ & $00.0 \pm 00.0 * *$ \\
\hline Trees with 6-10 lianas (\%) & $18.1 \pm 05.2 *$ & $00.0 \pm 00.0 * *$ \\
\hline Trees with > 10 lianas $(\%)$ & $09.0 \pm 06.1 *$ & $00.0 \pm 00.0^{* *}$ \\
\hline \multicolumn{3}{|l|}{ Availability of strata } \\
\hline Foliage density (\%) from 0 to $2 \mathrm{~m}$ & $13.3 \pm 03.7$ & $04.3 \pm 06.0$ \\
\hline Foliage density $(\%)$ from 2 to $5 \mathrm{~m}$ & $17.2 \pm 08.2$ & $28.7 \pm 05.0$ \\
\hline Foliage density (\%) from 5 to $10 \mathrm{~m}$ & $28.3 \pm 07.1 *$ & $14.4 \pm 03.5^{* *}$ \\
\hline Foliage density (\%) from 10 to $15 \mathrm{~m}$ & $18.7 \pm 15.6$ & $17.3 \pm 07.4$ \\
\hline Foliage density (\%) from 15 to $20 \mathrm{~m}$ & $13.8 \pm 09.9$ & $10.9 \pm 04.2$ \\
\hline Foliage density (\%) from 20 to $25 \mathrm{~m}$ & $08.8 \pm 32.6$ & $24.5 \pm 03.3$ \\
\hline Total occupied for vegetation (m) & 854.8 & 689.0 \\
\hline \multicolumn{3}{|c|}{ Availability of alternative foraging, defecating and resting sites } \\
\hline Density of feeding trees & $163.3 \pm 61.1$ & $60.0 \pm 87.1$ \\
\hline Density of trees with tangle of lianas & $140.0 \pm 10.0^{*}$ & $00.0 \pm 00.0^{* *}$ \\
\hline Density of trees with bromeliads & $00.0 \pm 00.0 *$ & $23.3 \pm 05.8 * *$ \\
\hline Density of trees with hollows & $03.3 \pm 00.58$ & $10.0 \pm 10.0$ \\
\hline Density of palm trees & $40.0 \pm 17.3^{*}$ & $03.3 \pm 05.8^{* *}$ \\
\hline
\end{tabular}

\footnotetext{
${ }^{a}$ Density data refer to number of trees per ha calculated with values obtained in sample plots $(10$ plots, $10 \times 10 \mathrm{~m})$.

${ }^{\mathrm{b}}$ Mean and $S D$ values of variables obtained in each habitat. Values within a row followed by different number of asterisks are significantly different (Mann-Whitney test; $P<0.05)$.
}

area-observation curves indicated that for most individuals, the MPC was a proxy adequate to portray porcupine's home range (Supporting Information S1). The porcupines exhibited small home-range sizes (2.7 ha) with wide variation among individuals (0.5-9.46 ha). These values are similar to those observed previously in another Atlantic Forest fragment (2.14 ha; 0.5-3.9 ha-Oliveira et al. 2012), but they were smaller than the 15.8 ha observed for a single translocated individual monitored by Zortéa and de Brito (2010). However, this home-range size is probably inflated due to dispersal movements after translocation.

The observed home-range size was similar to those reported for other similar-sized (1-2 kg) Neotropical erethizontids, such as Coendou villosus (6.3 ha-Passamani 2010) and Coendou mexicanus (10 ha-Estrada and Coates-Estrada 1985), while smaller than those estimated for larger erethizontids $(\geq 3 \mathrm{~kg})$, such as Coendou prehensilis (17.2-38 ha-Montgomery and Lubin 1978; Santos-Junior 1998) and Erethizon dorsata (63.9-106.6 ha-Dodge and Barnes 1975; Smith 1979; Roze 1987, 2009). The small home-range size was below values estimated for herbivores with the same body weight, based on data reported by Damuth (1981), and similar to other strict arboreal folivorous mammals with comparable body masses (e.g., Avahi laniger [1-4 ha] and Dendrohyrax arboreus [0.4-4.1 ha]Harcourt 1991; Comport et al. 1996). This corroborates the requirements of arboreal folivorous mammals for small homerange areas (Eisenberg 1978).
We detected significant differences in home-range patterns between sexes. The average male home-range size was at least 3 times larger than the female size. Male home ranges almost completely overlapped with those of females, whereas females overlapped only a small proportion with other females. This was also observed for the North American porcupine Erethizon dorsata (Dodge and Barnes 1975; Sweitzer 2003; Roze 2009), which shows mate-defense polygyny where male reproductive success depends largely on the number of females they can monopolize (Sweitzer 2003). Although information regarding the thin-spined porcupine's mating system is lacking, the size and overlapping differences of home range between sexes are compatible with a polygynic mating system.

Multiscale habitat selection.-Generally, habitat selection did not change markedly across the scales. We could identify specific structural features often associated with this selection. At finer scales, tagged porcupines avoided trees with lower DBH, while at a coarse scale, forest types with smaller trees such as early secondary forest were avoided or not selected. There was no preference for trees or vegetation types with fewer lianas, such as SCPs. In contrast, porcupines preferred trees and vegetation types with larger trees harboring many lianas, such as secondary forests and their edges. Ground, open areas, and rubber plantations were not used. Therefore, the species showed clear preference for complex habitats and avoidance of 
structurally simpler habitats with few and less developed vertical strata (as defined by August 1983).

The animals reacted to habitat conditions that may affect their fitness (Buskirk and Millspaugh 2006). Predation risk likely decreases with tall trees by limiting access to terrestrial predators (Sweitzer and Berger 1992). Considering that DBH is positively related to tree height (O'Brien et al. 1995), preference for higher DBH may be a commonly observed predatoravoidance behavior for arboreal mammals (Griesemer et al. 1998; Milner and Harris 1999; Cunningham et al. 2004). Thinspined porcupines generally do not rest or travel on the top of tree crowns (possibly to avoid aerial predators), but quickly climb to the tree tops after detecting potential terrestrial predator activity (G. A. F. Giné, pers. obs.). Thus, the use of tall trees with a high amount of lianas (for quick escape to other trees) is probably advantageous.

Larger trees $(\mathrm{DBH}>30 \mathrm{~cm})$ close to forest limits $(\mathrm{PFL}<$ $10 \mathrm{~m}$ ) were preferentially visited during feeding. Because these trees are likely to be exposed to the sunlight and can also develop wider crowns, these conditions may enhance the biomass production and nutritional quality of leaves (Johns and Skorupa 1987; Ganzhorn 1995; O'Brien et al. 1995; Lehman et al. 2006; Calvo-Alvarado et al. 2008). Thus, in addition to the potential reduction of predation risk, the preference for such trees for feeding should maximize food and nutrient intake. This behavior is probably important due to energetically constrained diets (Giné et al. 2010).

The amount of lianas also influenced tree selection and was particularly associated with activities such as travel and diurnal rest. Lianas likely increase connectivity among tree crowns and facilitate movements across the forest canopy. This may reduce the energy cost of mobility and predation risk by reducing the need to descend to the ground (Montgomery and Sunquist 1978; Emmons 1995). Porcupines cannot leap between trees and instead rely on prehensile tails and a "pincer grip" for support (Emmons 1995). Thus, they may particularly depend on lianas for efficient locomotion.

The preference for trees heavily infested with lianas $(\geq 10$ lianas) seems to reflect the predominant use of tangles of lianas as diurnal resting sites, which is commonly observed for this species (Chiarello et al. 1997; Giné et al. 2012; Oliveira et al. 2012) and other South American porcupines (CharlesDominique et al. 1981; Monterrubio-Rico et al. 2010; Passamani 2010). Besides providing covered places for hiding from predation during the day, the tangles also protect from wind and rain (Giné et al. 2012). These tangles and some pioneer species preferred by porcupines (e.g., I. thibaudiana; Giné et al. 2010) tend to concentrate in the forest edges (CharlesDominique et al. 1981; G. A. F. Giné, pers. obs.). However, considering the negative effect of proximity to forest edges on the frequency of visits to trees for diurnal rest, the feeding resource distribution may better explain the preference of areas closer to forest limits.

Early secondary forest and other highly modified vegetation types such as pastures and shade plantations were avoided or not selected, in contrast to anecdotal information of SCPs being suitable habitats (Moojen 1952; Nowak and Paradiso 1983). In our study, thin-spined porcupines only used these plantations as a marginal environment, particularly for defecation, probably isolating waste to avoid detection by predators and parasites, a strategy typically reported for other mammals (Hutchings et al. 2006).

Notwithstanding, SCPs are suitable habitats for many local animals, including many forest dwellers (Faria et al. 2007; Cassano et al. 2011, 2014a, 2014b). Curiously, shade plantations have high concentrations of food and shelter resources commonly used by thin-spined porcupines, even in similar densities to that in native forests. What makes this vegetation type unsuitable for the focal species? We suggest that the scattered remnants of canopy trees with few lianas and less developed middle strata create structural canopy discontinuities preventing canopy movement and making the habitat unsuitable for this species.

Predation risk in SCPs, rubber plantations, and open areas must also be greater due to human presence and greater exposure in these habitats. Potential nonhuman predators such as domestic dogs (Canis lupus familiaris), crab-eating foxes (Cerdocyon thous), tayra (Eira barbara), and wild cats (Leopardus wiedii and L. tigrinus) are common in the SCPs (Cassano et al. 2014a). Sharp quills may allow other porcupine species to exploit simpler habitats and on the ground with low predation risks (Sweitzer and Berger 1992). For example, Coendou insidiosus and C. prehensilis apparently are able to explore more habitats, including disturbed and simplified habitats such as plantations, fruit crops, scrubs, and open areas (Oliver and Santos 1991; Santos-Junior 1998). However, the thin-spined porcupines are mostly covered with soft bristles rather than quills (Giné et al. 2012), so antipredation strategies may be more important (Giné et al. 2012). Despite poor understanding of spatial ecology for several Neotropical species, C. subspinosus seems to have more arboreal and restricted habitat requirements among erethizontids.

The structural simplification of the canopy of SCPs is an important feature negatively influencing the occurrence of other canopy mammals such as the Wied's black-tufted ear marmoset (Callithrix kuhlii) and the golden-headed lion tamarin (Leontopithecus chrysomelas - Cassano et al. 2014a), although these species often use shade plantations as temporary or even primary habitats (Raboy and Dietz 2004; Oliveira et al. 2011b). Among canopy mammals from this region (see Cassano et al. $2014 \mathrm{~b}$ for a review), the thin-spined porcupine was notably the only species not using SCPs, even when considering similarsized arboreal species.

Concluding remarks. - The results support the importance of native secondary forests as primary habitats for this species. SCPs seem to be unsuitable despite previous beliefs. This information is critical for any conservation strategies. Considering that less than $17 \%$ of the native forest cover still exists in their geographic distribution (Ribeiro et al. 2009), the dependence of the species on native forests and its low adaptability to humanmodified forested habitats draws a pessimistic scenario. These 
results further support the idea that not only habitat loss through deforestation (Chiarello et al. 2008; Faria et al. 2011; IUCN 2014), but also conversion to shade plantations are important drivers of population decline. In fact, the avoidance of such matrix habitats may be one cause of the critical genetic erosion in this region (Oliveira et al. 2011a).

On the other hand, a positive point is that the individuals present small area requirements and high adaptability to forest patches disturbed by edge effects, which characterize much of the remaining forest patches in their distribution (Ribeiro et al. 2009). Edge effects favor liana and pioneer species proliferation (Laurance et al. 2002), 2 resources largely used by thin-spined porcupine. With these biological characteristics, conservation efforts aimed at preserving and increasing forest remnant connectivity could provide structural and functional landscapes (see Lidicker 1999) and potentially increase longterm persistence, providing that other disturbances such as hunting (Castilho et al. 2013) and fire (Faria et al. 2011) are under control.

\section{ACKNOWLEDGMENTS}

The study was funded by the Ministério do Meio Ambiente do Brasil (MMA), Fundação de Amparo à Pesquisa do Estado de São Paulo (FAPESP), Conselho Nacional de Desenvolvimento Científico e Tecnológico (CNPq), and Coordenação de Aperfeiçoamento de Pessoal de Nível Superior (CAPES). The Brazilian Environmental Agency (ICMBio) provided authorization for capturing, handling, and radiotracking of the animals (license number: 191/2004; 125/2005; 23468-1/2/3). We are grateful for the aerial photographers from the Instituto de Estudos Sócio-Ambientais do Sul da Bahia (IESB) and the owners and managers of the farms and protected areas of the sampling sites. We thank U. Roze, E. Vieira, and anonymous reviewers for comments on an earlier draft and C. da Rosa for helping us with GLMM analysis.

\section{SUPPORTING INFORMATION}

The Supporting Information documents are linked to this manuscript and are available at Journal of Mammalogy online (jmammal.oxfordjournals.org). The materials consist of data provided by the author that are published to benefit the reader. The posted materials are not copyedited. The contents of all supporting data are the sole responsibility of the authors. Questions or messages regarding errors should be addressed to the author.

Supporting Information S1.-Area-observation curves describing the effect of sample size on home range estimation of the radiocollared thin-spined porcupines.

Supporting Information S2.-Locations, home ranges, and surrounding landscapes of radiocollared thin-spined porcupines.

\section{Literature Cited}

Altmann, J. 1974. Observational study of behavior: sampling methods. Behavior 49:227-267.
August, P. V. 1983. The role of habitat complexity and heterogeneity in structuring tropical mammal communities. Ecology 64:1495-1507.

Boyd, C., ET AL. 2008. Spatial scale and the conservation of threatened species. Conservation Letters 1:37-43.

Burnham, K. P., And D. R. Anderson. 2002. Model selection and multimodel inference: a practical information-theoretic approach. 2nd ed. Springer-Verlag, New York.

Buskirk, S. W., and J. J. Millspaugh. 2006. Metrics for studies of resource selection. Journal of Wildlife Management 70:358-366.

Byers, C. R., R. K. Steinhorst, and P. R. Krausman. 1984. Clarification of a technique for analysis of utilization-availability data. Journal of Wildlife Management 48:1050-1053.

Calvo-Alvarado, J. C., N. G. McDowell, and R. H. Waring. 2008. Allometric relationships predicting foliar biomass and leaf area: sapwood area ratio from tree height in five Costa Rican rain forest species. Tree Physiology 28:1601-1608.

Cassano, C. R., J. Barlow, and R. Pardini. 2014a. Forest loss or management intensification? Identifying causes of mammal decline in cacao agroforests. Biological Conservation 169:14-22.

Cassano, C. R., M. C. M. Kierulff, and A. A. G. Chiarello. 2011. The cacao agroforests of the Brazilian Atlantic Forest as habitat for the endangered maned sloth Bradypus torquatus. Mammalian Biology 76:243-250.

Cassano, C. R., ET AL. 2014b. Desafios e recomendações para a conservação da biodiversidade na região cacaueira do sul da Bahia. Centro de Pesquisas do Cacau. Boletim Técnico 205:1-52.

Castilho, L. C., R. A. Martinez, G. A. F. Giné, G. C. Ribeiro, AND A. SchiavetTi. 2013. The thin-spined porcupine, Chaetomys subspinosus (Rodentia: Erethizontidae), within protected areas in the Atlantic Forest, Brazil: local knowledge and threats. Tropical Conservation Science 6:796-810.

Charles-Dominique, P., M. Atramentowicz, G. H. CharlesDominique, A. Hladick, C. M. Hladick, and M. F. Prévost. 1981. Les mammiferes frugivores arboricoles nocturnes d'une forêt guyanaise: inter-relations plantes-animaux. Revue d'Écologie (La Terre et la Vie) 35:341-435.

Chiarello, A. G., L. M. S. Aguiar, R. Cerqueira, F. R. Melo, F. H. G. Rodrigues, And V. M. F. Silva. 2008. Mamíferos ameaçados de extinção no Brasil. Pp. 680-874 in Livro vermelho da fauna brasileira ameaçada de extinção (A. B. M. Machado, G. M. Drummond, and A. P. Paglia, eds.). MMA/Fundação Biodiversitas, Brasília, Brazil.

Chiarello, A. G., M. Passamani, and M. Zortéa. 1997. Field observations on the thin-spined porcupine, Chaetomys subspinosus (Rodentia; Echimyidae). Mammalia 61:29-36.

Comport, S. S., S. J. WARd, AND W. J. Foley. 1996. Home ranges, time budget and food-tree use in a high-density tropical population of greater gliders, Petauroides volans minor (Pseudocheiridae: Marsupialia). Wildlife Research 23:401-419.

CONAMA. 1994. Resolução CONAMA nº5 de 04 de maio de 1994. http://www.mma.gov.br/port/conama/legislacao/CONAMA_RES_ CONS_1994_005.pdf. Accessed 8 October 2014.

Cunningham, R. B., M. L. Pope, And D. B. Lindenmayer. 2004. Patch use by the greater glider (Petauroides volans) in a fragmented forest ecosystem. III. Night-time use of trees. Wildlife Research 31:579-585.

DAmuth, J. 1981. Home ranges, home range overlap, and species energy use among herbivorous mammals. Biological Journal of the Linnean Society 15:185-193. 
De Souto Lima, R. B., P. A. Oliveira, and A. G. Chiarello. 2010. Diet of the thin-spined porcupine (Chaetomys subspinosus), an Atlantic forest endemic threatened with extinction in southeastern Brazil. Mammalian Biology 75:538-546.

Dodge, W. E., AND V. G. BARnes. 1975. Movements, home range and control of porcupines in western Washington. United States Department of the Interior, Fish and Wildlife Service, Wildlife leaflet 507, Washington, D.C.

EisenberG, J. F. 1978. The evolution of arboreal herbivores in the class Mammalia. Pp. 135-152 in The ecology of arboreal folivores (G. G. Montgomery, ed.). Smithsonian Institution Press, Washington, D.C.

Emmons, L. H. 1995. Mammals of rain forest canopies. Pp. 199223 in Forest canopies (M. D. Lowland and N. M. Nadkarni, eds.). Academic Press, San Diego, California.

Environmental Systems Research Institute, InC. 1999. ArcView GIS. Version 3.2. Environmental Systems Research Institute, Inc., Redlands, California.

Estrada, A., AND R. CoATES-Estrada. 1985. A preliminary study of resource overlap between howling monkeys (Alouatta palliata) and other arboreal mammals in the tropical rainforest of Los Tuxtlas, Mexico. American Journal of Primatology 9:27-37.

Faria, D., F. A. Gaiotto, and G. A. F. Giné. 2011. Plano de Ação Nacional para a Conservação do ouriço-preto. Instituto Chico Mendes de Conservação da Biodiversidade, Brasília, Brazil. http:// www.icmbio.gov.br/portal/images/stories/docs-plano-de-acao/panourico-preto/livro_ourico_preto_web.pdf. Accessed 9 July 2014.

Faria, D., M. L. B. Paciencia, M. Dixo, R. R. Laps, and J. Baumgarten. 2007. Ferns, frogs, lizards, birds and bats in forest fragments and shade cacao plantations of two contrasting landscapes in the Atlantic forest, Brazil. Biodiversity and Conservation $16: 2335-2357$.

GANZHORN, J. U. 1995. Low-level forest disturbance effects on primary production, leaf chemistry, and lemur populations. Ecology 76:2084-2096.

Giné, G. A. F., J. M. B. Duarte, and D. Faria. 2010. Feeding ecology of a selective folivore, the thin-spined porcupine (Chaetomys subspinosus) in the Atlantic forest. Journal of Mammalogy 91:931-941.

Giné, G. A. F., J. M. B. Duarte, T. C. S. Motta, and D. Faria. 2012. Activity, movement and secretive behavior of a threatened arboreal folivore, the thin-spined porcupine, in the Atlantic forest of southern Bahia, Brazil. Journal of Zoology (London) 286:131-139.

Griesemer, S. J., T. K. Fuller, and R. M. DeGraAf. 1998. Habitat use by porcupines (Erethizon dorsatum) in central Massachusetts: effects of topography and forest composition. American Midland Naturalist 140:271-279.

Harcourt, C. 1991. Diet and behaviour of a nocturnal lemur, Avahi laniger, in the wild. Journal of Zoology (London) 223:667-674.

Holt, R. D., and M. Barfield. 2008. Habitat selection and niche conservatism. Israel Journal of Ecology and Evolution 54:295-309.

Hooge, P. N., And B. Eichenlaub. 1997. Animal movement extension to ArcView. Version 2.04. United States Geological Survey, Alaska Biological Science Center, Anchorage.

Hubbell, S. P., and R. B. Foster. 1986. Canopy gaps and the dynamics of a Neotropical forest. Pp. 77-95 in Plant ecology (M. J. Crawley, ed.). Blackwell, Oxford, United Kingdom.

Hutchings, M. R., J. Judge, I. J. Gordon, S. Athanasiadou, and I. KyRIAZAKIS. 2006. Use of trade-off theory to advance understanding of herbivore-parasite interactions. Mammal Review 36:1-16.
InTERNATIONAL UNION FOR THE CONSERVATION OF NATURE. 2014. IUCN Red List of threatened species. Version 2014.1. http://www. iucnredlist.org. Accessed 9 July 2014.

Johns, A. D., AND J. P. Skorupa. 1987. Responses of rain-forest primates to habitat disturbance: a review. International Journal of Primatology 8:157-191.

Johnson, D. H. 1980. The comparison of usage and availability measurements for evaluating resource preference. Ecology 61:65-71.

Kernohan, B. J., R. A. Gitzen, And J. Millspaugh. 2001. Analysis of animal space use and movements. Pp. 125-166 in Radio tracking and animal populations (J. J. Millspaugh and J. M. Marzluff, eds.). Academic Press, San Diego, California.

Laundré, J. W., And B. L. Keller. 1984. Home range size of coyotes: a critical review. Journal of Wildlife Management 48:127-139.

Laurance, W. F, ET AL. 2002. Ecosystem decay of Amazonian forest fragments: a 22-year investigation. Conservation Biology 16:605-618.

Leban, F. A. 1999. Resource selection for Windows. Version 1.00. University of Idaho, Moscow. https://www.msu.edu/course/ fw/424/Fred Leban/Resource Selection/. Accessed 9 July 2014.

Lehman, S. M., A. Rajaonson, and S. Day. 2006. Edge effects and their influence on lemur density and distribution in southeast Madagascar. American Journal of Physical Anthropology 129:232-241.

LIDICKER JR., W. Z. 1999. Responses of mammals to habitat edges: an overview. Landscape Ecology 14:333-343.

May, P. H., AND E. R. B. Rocha. 1996. O sistema agrossilvicultural do cacau-cabruca. Pp. 35-61 in Gestão ambiental no Brasil: experiência e sucesso (I. V. Lopes, G. S. B. Filho, and D. Biller, eds.). Fundação Getúlio Vargas Editora, São Paulo, Brazil.

Milner, J. M., AND S. Harris. 1999. Activity pattern and feeding behavior of the tree hyrax, Dendrohyrax arboreus, in the Park National des Volcans, Rwanda. African Journal of Ecology 37:267-280.

Mohr, C. O. 1947. Table of equivalent populations of North American small mammals. The American Midland Naturalist Journal 37:223-249.

Monterrubio-Rico, T. C., J. M. Ortega-Rodríguez, N. MendozaCárdenas, R. Cancino-Murillo, and A. Pérez-Arteaga. 2010. Distributional and ecological records of the mexican hairy dwarf porcupine (Sphiggurus mexicanus) from Michoacan, Mexico. The Southwestern Naturalist 55:139-142.

Montgomery, G. G., And Y. D. Lubin. 1978. Movements of Coendou prehensilis in the Venezuelan Llanos. Journal of Mammalogy 59:877-888.

Montgomery, G. G., AND M. E. SunQuist. 1978. Habitat selection and use by two-toed and three-toed sloths. Pp. 329-359 in The ecology of arboreal folivores (G. G. Montgomery, ed.). Smithsonian Institution Press, Washington, D.C.

Moojen, J. 1952. Os roedores do Brasil. v. 1. Instituto Nacional do Livro, Rio de Janeiro, Brazil.

Mori, S. A., B. M. Boom, A. M. de Carvalho, and T. S. dos SAntos. 1983. Southern Bahian moist forest. The Botanical Review 49:155-232.

Morin, P., D. Berteux, And I. Klvana. 2005. Hierarchical habitat selection by North American porcupines in southern boreal forest. Canadian Journal of Zoology 83:1333-1342.

Neu, C. W., C. R. Byers, and J. M. Peek. 1974. A technique for analysis of utilization-avalability data. Journal of Wildlife Management 38:541-545. 
NowAK, R. M., AND J. L. PARADISO. 1983. Walker's mammals of the world. Johns Hopkins University Press, Baltimore, Maryland.

O’Brien, T. S., S. P. Hubbell, P. Spiro, R. Condit, and R. B. Foster. 1995. Diameter, height, crown, and age relationship in eight neotropical tree species. Ecology 76:1926-1939.

Odum, E. P., AND E. J. Kuenzler. 1955. Measurement of territory and home range size in birds. Auk 72:128-137.

Oliveira, C. G., R. A. Martinez, G. A. F. Giné, D. M. Faria, And F. A. Gaiotto. 2011a. Genetic assessment of the Atlantic Forest bristle porcupine, Chaetomys subspinosus (Rodentia: Erethizontidae), an endemic species threatened with extinction. Genetics and Molecular Research 10:923-931.

Oliveira, L. C., L. G. Neves, B. E. Raboy, and J. M. Dietz. 2011b. Abundance of jackfruit (Artocarpus heterophyllus) affects group characteristics and use of space by golden-headed lion tamarins (Leontopithecus chrysomelas) in cabruca agroforest. Environmental Management 48:248-262.

Oliveira, P. A., R. B. De Souto-Lima, And A. G. Chiarello. 2012. Home range, movements and diurnal roosts of the endangered thinspined porcupine, Chaetomys subspinosus (Rodentia: Erethizontidae), in the Brazilian Atlantic Forest. Mammalian Biology 77:97-107.

Oliveira-Filho, A. T., And M. A. L. Fontes. 2000. Patterns of floristic differentiation among Atlantic forest in southeastern Brazil and the influence of climate. Biotropica 32:793-810.

Oliver, W. L. R., AND I. B. SAntos. 1991. Threatened endemic mammals of the Atlantic forest region of south-east Brazil. Special Scientific Report 4. Jersey Wildlife Preservation Trust, Jersey, Channel Islands.

PARdini, R., ET AL. 2009. The challenge of maintaining Atlantic forest biodiversity: A multi-taxa conservation assessment of specialist and generalist species in an agro-forestry mosaic in southern Bahia. Biological Conservation 142:1178-1190.

Passamani, M. 2010. Use of space and activity pattern of Sphiggurus villosus (F. Cuvier, 1823) from Brazil (Rodentia: Erethizontidae). Mammalian Biology 75:455-458.

Raboy, B. E., AND J. M. Dietz. 2004. Diet, foraging, and use of space in wild golden-headed lion tamarins. American Journal of Primatology 63:1-15.

R Development Core Team. 2013. R: a language and environment for statistical computing. Version 3.0.0. R Foundation for Statistical Computing, Vienna, Austria. http://www.R-project.org. Accessed 10 July 2013.

Ribeiro, M. C., J. P. Metzger, A. C. Martensen, F. J. Ponzoni, AND M. M. HiRota. 2009. The Brazilian Atlantic Forest: how much is left, and how is the remaining forest distributed? Implications for conservation. Biological Conservation 142:1141-1153.

Roze, U. 1987. Denning and winter range of the porcupine. Canadian Journal of Zoology 65:981-986.

Roze, U. 2009. The North American porcupine. 2nd ed. Cornell University Press, Ithaca, New York.
SAmbuichi, R. H. R. 2002. Fitossociologia e diversidade de espécies arbóreas em cabruca (Mata Atlântica raleada sobre plantação de cacau) na região sul da Bahia, Brasil. Acta Botânica Brasilica 16: 89-101.

SAntos-Junior, T. S. 1998. Monitoramento de Coendou prehensilis (Rodentia: Erethizonthidae) resgatados no reservatório da Usina Hidrelétrica de Miranda (MG) e translocados para a Reserva do Jacob, Nova Ponte - MG. M.S. thesis, Universidade Federal de Brasília, Brasília, Brazil.

SIEGEL, S. 1956. Nonparametric statistics for the behavioral sciences. McGraw-Hill, New York.

Sikes, R. S., W. L. Gannon, and the Animal Care and Use Committee of the American Society of Mammalogists. 2011. Guidelines of the American Society of Mammalogists for the use of wild mammals in research. Journal of Mammalogy 92: 235-253.

Smith, G. W. 1979. Movements and home range of the porcupine in northeastern Oregon. Northwest Science 53:277-282.

SPENCER, W. D. 2012. Home ranges and value of spatial information. Journal of Mammalogy 93:929-947.

Sweitzer, R. A. 2003. Breeding movements and reproductive activities of porcupines in the great basin desert. Western North American Naturalist 63:1-10.

Sweitzer, R. A., AND J. Berger. 1992. Size-related effects of predation on habitat use and behavior of porcupines (Erethizon dorsatum). Ecology 73:867-875.

Thomas, W. M. W., A. M. V. Carvalho, A. M. A. Amorim, J. Garrison, And A. L. Arbeláez. 1998. Plant endemism in two forests in southern Bahia, Brazil. Biodiversity and Conservation 7:311-322.

Vilela, R. V., T. Machado, K. Ventura, V. Fagundes, M. J. Silva, And Y. Yonenaga-Yassuda. 2009. The taxonomic status of the endangered thin-spined porcupine, Chaetomys subspinosus (Olfers, 1818), based on molecular and karyologic data. BioMed Central Evolutionary Biology 9:29-46.

Voss, R. S., C. Hubbard, and S. A. Jansa. 2013. Phylogenetic relationships of New World porcupines (Rodentia, Erethizontidae): implications for taxonomy, morphological evolution, and biogeography. American Museum Novitates 3769:1-36.

Worton, B. J. 1989. Kernel methods for estimating the utilization distribution in home range studies. Ecology 70:164-168.

ZortéA, M., AND B. F. A. DE BRITO. 2010. Diurnal roosts and minimum home range defined by sleeping sites of a thin-spined porcupine Chaetomys subspinosus (Rodentia: Erethizontidae). Zoologia 27:209-212.

Submitted 31 July 2014. Accepted 25 June 2015.

Associate Editor was Marcus V. Vieira. 